\title{
Recognizing vegetation chronosequence in Landsat imagery
}

\author{
Reconocimiento de la secuencia cronológica de la vegetación en imágenes Landsat
}

\author{
Irina Danilova ${ }^{a *}$, Vera Ryzhkova a, Michael Korets ${ }^{\text {a }}$ \\ *Corresponding author: ${ }^{\text {a }}$ Siberian Br., Russian Academy of Sciences, V.N. Sukachev Institute of Forest, \\ GIS Laboratory, 660036 Krasnoyarsk, Russia, tiv@ksc.krasn.ru
}

\begin{abstract}
SUMMARY
This paper presents a description of an algorithm of automated identification of forest regeneration stages using a spatial analysis of Landsat-5 TM imagery and field data. Based on this algorithm, several raster maps were built to show the vegetation regeneration stages in a range of habitat types found in southern Yenisey Siberia.
\end{abstract}

Key words: remote sensing data, GIS, forest regeneration dynamics map.

\section{RESUMEN}

Este trabajo presenta la descripción de un algoritmo que permite identificar automáticamente los estados de la regeneración del bosque usando un análisis espacial de imágenes Landsat-5 TM y datos de campo. Basándose en este algoritmo, varios mapas raster fueron creados para mostrar los estados de la regeneración de la vegetación en un rango de tipos de hábitat encontrados en el sur de Yenisey, Siberia.

Palabras clave: datos de sensores remotos, SIG, mapa de dinámica de regeneración forestal.

\section{INTRODUCTION}

Siberian boreal forests have been drastically altered over the past sixty years by increasing logging activity, industrial projects, areas burned by wildfires, and devastated by pest outbreaks. These alterations have resulted in a deep disturbance of forest ecosystem equilibrium and have induced forest biodiversity and ecological function reduction. This necessitates the development of new methodologies of forest resource recovery estimation and prediction (Pontus 2005).

Maps created using traditional methods become out of date very soon. At present, creating new or updating old maps involves the use of satellite images and GIS (geographic information system) technologies in combination with traditional mapping methods. We have developed a methodology of automated recognition of forest regeneration stages based on a spatial analysis of remote sensing and ground data. Recognition accuracy mainly depends on the spectral characteristics of a given surface provided by the same space-borne instrument and the image classification algorithms applied; different woody species are recognized with different confidence levels. The major problem here is that spectral characteristics of many vegetation types overlap making hampering their differentiation. While deciduous species are easy to segregate from dark conifers, the segregation becomes problematic where light conifers come in. In this case the differentiation bet- ween species close in their spectral characteristics, as for example, between Picea obovata (Ledeb.) (spruce) and Abies sibirica (Ledeb.) (fir), Pinus sylvestris L. (pine) and Larix sibirica (Ledeb.) (larch), Betula pendula Roth (birch) and Populus tremula L. (aspen), is usually not possible (Napryushkin 2002). To recognize woody species composition, it is reasonable to use diverse moderate-resolution images received from the same instrument and to involve various data from other sources for image detailing (Maslov 2005).

Automated recognition requires the identification of elementary forest vegetation sites similar in woody species composition and age, which are referred to as community type. Each elementary site (or elementary unit) represents a certain vegetation age stage and is used to build a vegetation chronosequence (Kolesnikov 1956, Ryzhkova 2007).

\section{METHODS}

We selected the southern part of Yenisei Siberia as the test site. This extremely topographically non-uniform area encompasses a plain part of West Siberian Lowland west of and the low mountains of Yenisei Mountain Ridge and Usol Hollow east of Yenisei. The test site vegetation cover is composed of subtaiga forests broken in places by foreststeppe sites and croplands. The forest communities are diverse regarding woody species composition, structure, and regeneration characteristics. These forests have been 
heavily disturbed by human activities and all stages of the major woody species regeneration are, therefore, found across vast areas in a wide range of habitats.

We analyzed satellite images in a stepwise way, with GIS technologies and the standard procedures of ERDAS IMAGINE 9.2 and ESRI ArcMap 9.3 being applied at each step.

Satellite data processing involved several stages. The first stage was preliminary data processing that included image geometrical correction and transformation to a desirable map projection, georeference, as well as topographic normalization. The images were converted into the basic map projection (UTM zone 46) to be then superposed on the forest fund data layer for a spatial analysis. To artificially equalize the extents of slope insolation, the images were topographically normalized using SRTM-3-DEM. The images were then combined to obtain multitemporal image.

At the second stage, reference samples for the supervised image classification were formed, based on the results of a joint analysis of the images and vector maps of elementary forest inventory sites (Korets et al. 2007). In effort to create reference samples, the main statistical indicators were calculated for each elementary forest inventory site using the set of the pixels of the image raster layers that occurred within a given elementary forest inventory site. Prior to this operation, elementary forest inventory site marginal pixels were discarded to reduce the effect of the map superposition-caused error.

The similarity of elementary forest inventory sites was judged from the standard deviation of remotely-based attribute values of elementary forest inventory sites. The final ranking of elementary forest inventory sites by similarity was done by crossing the sets of elementary forest inventory sites, which appeared to be relatively similar in most attributes. The elementary forest inventory sites most similar in spatial structure were included into the model sample.

The selected set of the relatively similar elementary forest inventory sites was based upon to form information class samples for the following image classification by major woody species and ages. Each information class had several corresponding elementary forest inventory sites, the contours of which were used to identify training sample boundaries. These samples were then based upon to calculate information class parametric signatures for the following image classification through training.

At the third stage, the satellite images were classified by the method of maximum likelihood and generalized using a fuzzy composition approach considering the contextual information on pixel interlocation (ERDAS 1999). Finally, the classes obtained were interpreted by an expert as forest vegetation age or regeneration stages with the help of forest inventory data.

To correctly classify and understand the position of any one vegetation type in a vegetation chronosequence and to assess its current state, one needs to know the habitat characteristics controlling the probability of occurrence of any vegetation community type. To build a forest vegetation chronosequence layer, an expert classification based on the Knowledge Engineering Module (ERDAS 1999) was developed. The results of the analyses of the satellite images and habitat raster layer (Ryzhkova et al. 2011) were used as the input data for building the expert classification.

\section{RESULTS}

Using the above methods, we developed a classification of forest vegetation. To do this, we used four summer (June-July) and four autumn (September-October) cloudfree Landsat 5 (TM) scenes (1989-1990 years) received as close as possible to the periods of field studies and ground forest inventory.

The selected images were converted into the basic map projection and topographically normalized. The normalized images were then combined to obtain four 12-band multitemporal images, each consisting of six bands of a summer image and six bands of an autumn image. We excluded the thermal band from each set of initial seven bands of Landsat 5 (TM) images.

To classify multitemporal images, the training samples for major woody species and age were made. Moreover the training samples were made so that minor woody species be also considered. Secondary (i.e., disturbance-induced deciduous) stands were analyzed based on the major woody vegetation spread trends. The deciduous stands containing a minor component of dark conifers were concluded to be secondary stands characteristic of dark conifers, whereas the stands containing Scots pine were concluded to replace light conifer forest where it had been disturbed. The information classes were formed through the elementary forest inventory site inventory database query. As a result, the information classes most common in a given part of the test site and the associated image were developed.

Then parametric signatures were calculated for each information class and a supervised classification of the images was done based upon these signatures. A generalized raster layer of surface spectrum-based elementary land cover classes was obtained using a fuzzy composition approach. The classes obtained were then visually assigned to the different forest regeneration stages by expert judgment with the help of all the available reference data (table 1).

A single classified image did not cover the entire test site and the overlapping images from either adjacent satellite pass were, therefore, used. Training samples for the overlap zone were developed automatically within the corresponding base image classes. Each image was classified separately to reduce effects of pixel spectral brightness variation among the images caused by certain vegetation phenophases and all kinds of atmospheric interferences.

To obtain a uniform class mosaic, all the classified ima- 
Table 1. Forest vegetation classes interpretation.

Interpretación de las clases de vegetación boscosa.

Forest vegetation chronosequence

Forest regeneration stages

Information class

(major woody species and age)

1. Scots pine/ tall grass/forb stands initial regeneration stages of light conifers birch_aspen_initial_stage supported by dark-colored sod forest soils and dark-grey loamy forest soils occur in watersheds and on the adjacent very soft slopes

\begin{tabular}{|c|c|}
\hline initial regeneration stages of light conifers & birch_aspen_initial_stage \\
\hline $\begin{array}{l}\text { young and middle-aged deciduous stands, } \\
\text { which replaced light conifers }\end{array}$ & $\begin{array}{l}\text { birch_aspen_5_20 (pine) } \\
\text { birch_aspen_20_40 (pine) }\end{array}$ \\
\hline $\begin{array}{l}\text { 40-80-yr-old mixed light conifer/ } \\
\text { deciduous stands }\end{array}$ & $\begin{array}{l}\text { pine_40_90_birch_60-80 } \\
\text { birch_aspen_(40-80)_pine >120 }\end{array}$ \\
\hline 80-120-yr-old light conifer stands & $\begin{array}{l}\text { pine_80_100 } \\
\text { pine_80_120_birch_>50 }\end{array}$ \\
\hline over 120-yr-old light conifer stands & pine_larix_>120 \\
\hline initial regeneration stages of dark conifers & birch_aspen_initial_stage \\
\hline $\begin{array}{l}\text { young and middle-aged deciduous stands, } \\
\text { which replaced dark conifers }\end{array}$ & $\begin{array}{l}\text { birch_fir_10_20 } \\
\text { birch_aspen_10_40 (fir) } \\
\text { aspen_birch_20_40 (fir) }\end{array}$ \\
\hline $\begin{array}{l}\text { 40-80-yr-old mixed light conifer/ } \\
\text { deciduous stands }\end{array}$ & $\begin{array}{l}\text { fir_spruce_60-80_birch_60_90 } \\
\text { birch_aspen_40-60 (fir) } \\
\text { birch_aspen_60_80 (fir) }\end{array}$ \\
\hline 80-120-yr-old dark conifer stands & fir_spruce_80_120_birch_70_100 \\
\hline over 120 -yr-old dark conifer stands & spruce_fir_>120 \\
\hline
\end{tabular}

2. Fir/spruce/tall grass/forb stands supported by dark-colored sod forest, darkgrey, and double-humus-horizon moderately loamy sod-podzolic soils on flattopped elevations and the adjacent soft slopes of an accumulative high plain

3. Mixed fir/spruce/grass stands on sodpodzolic and grey forest soils on an accumulative high plain slopes

ges were assembled in a certain sequence to ensure the best possible spatial superposition of overlapping classes.

To build a forest vegetation chronosequence layer in a stepwise manner we made the expert classification using the Knowledge Engineering Module. The elementary land cover classes obtained from remote sensing data classification were distributed among chronosequences (table 1) using a classification of habitat types and the associated forest vegetation (Ryzhkova et al. 2007).

Combined use of ground and remote sensing data, thematic maps, and DEM provided an overall picture of the forest communities found in southern Yenisei Siberia and made it possible to develop GIS layers of the vegetation age stages and chronosequence for this area (figure 1). Multitemporal images enabled to determine not only the major woody species and its age, but also secondary stand confinement to either dark or light conifer forest.

\section{DISCUSION AND CONCLUSIONS}

There exists neither uniform vegetation classification, nor satellite imagery-based vegetation cover map for Krasnoyarsk Region. The only forest vegetation maps in use nowadays are a 1:7 500000 map in the Atlas of Krasnoyarsk Region and the Republic of Khakasia (Doykhon 1994) and a 1:1 500000 USSR Forest Map (1973) containing out-of-date information. The forest regeneration dynamics map we developed through application of ground and satellite data for the southern part of Yenisei Siberia, which occurs within Krasnoyarsk Region, is of a scale of 1: 100 000. This map based on the dynamic forest type classification shows the vegetation by altitudinal vegetation belt, topography, and soil moisture regime, combines the major-species and secondary stands into genetic forest types, enables to assess current state of forest vegetation, and to predict its future recovery rate for as long as 200 years, which is the full logging rotation period in southern taiga forests.

As is clear from Kappa statistic $=0.74$, the satellite imagery classification quality corresponds to the excellent object recognition accuracy (Monserud and Leemans 1992). Therefore, the methodology proposed enables to achieve a relatively high accuracy of recognition of forest communities found in a range of environmental conditions. The automated satellite image classification combined with spatial analysis procedures, allow us to minimize human involvement in the process of thematic map development.

Scientific interest to classifications reflecting vegetation cover trends has increased over the past several decades due to ever-increasing forest transformations (Ivanova 2011). Russian scientists also participate in this research area. However, no such type of work is underway in Krasnoyarsk Region. For this reason, the characteristics of forest regeneration dynamics determined in this study for plain and lowmountain southern taiga forests are unique as to the level of detail and can be extrapolated to the same landscape types found within central Siberia to model forest succession in a similar range of environmental conditions. 


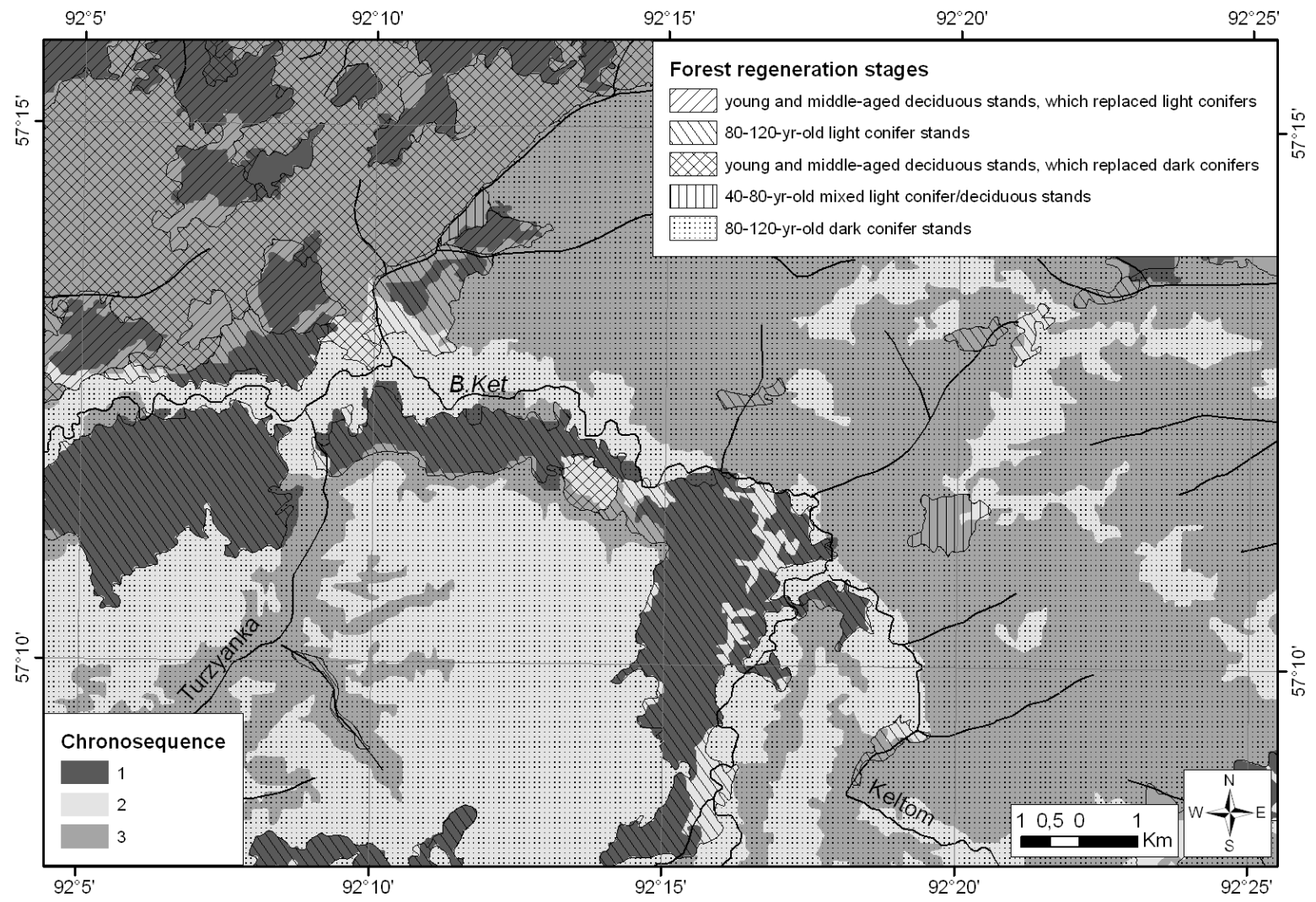

Figure 1. Fragment of two layers of the study area forest dynamics map.

Fragmento de dos capas del mapa que muestra la dinámica de bosques del área de estudio.

\section{ACKNOWLEDGEMENT}

This work was supported by Russian Fundamental Research Foundation Grants 10-05-00941-a, 11-04-98008P_Siberia_a, Project ZAPAS (Assessment and Monitoring of Forest Resources in the Framework of the EU-Russia Space Dialogue) and project $N^{\circ} 27.32$ program of the Presidium RAS.

\section{REFERENCES}

Doykhon GP. 1994. Vegetation Map (1:7 500 000). Atlas of Krasnoyarsk Region and the Republic of Khakasia. Novosibirsk, Russia. Roskartografia Press. p. 36-37.

ERDAS Field Guide. 1999. Fifth edition. USA: ERDAS Inc. $672 \mathrm{p}$.

Ivanova NS. 2011. Applying ecosystem and genetic approaches to forest type identification. International journal of experimental education 6: 8-9.

Kolesnikov BP. 1956. Siberian pine forests of the Russian Far East. Moscow-Leningrad, Russia. Nauka Press. 263 p.

Korets MA, IV Danilova, VP Cherkashin. 2007. Remote indication of forest landscape structure. In Onuchin AA ed. Regional Sustainable Forestry Problems. Krasnoyarsk, Rus- sia. Sukachev Institute of Forest Publications. p 52-68.

Maslov AA. 2006. Satellite monitoring of forest Russia: the current state, problems and prospects. Forest Bulletin 1(31): 12-17.

Monserud RA, RA Leemans. 1992. Comparing global vegetation maps with the Kappa statistic. Ecological Modeling 62: 275-293.

Napryushkin AA. 2002. Algorithms and soft packages for a system of aero-space imagery interpretation to map landscape objects. PhD Thesis Summary. Tomsk. 19 p.

Pontus AP. 2005. Complex evaluation and prediction forest resources dynamics on the basis of diverse aerospace information and GIS. Thesis. Remote sensing methods in forest management and inventory. Krasnoyarsk, Russia. V.N. Sukachev Institute of Forest, SB, RAS. p. 82-83.

Ryzhkova VA. 2007. Regeneration of subtaiga and mountain taiga forests. In Onuchin AA ed. Regional Sustainable Forestry Problems. Krasnoyarsk, Russia. Sukachev Institute of Forest Publications. p. 78-90.

Ryzhkova VA, IV Danilova, MA Korets, IA Mikhailova. 2011. Principles and methods to build a GIS-based map of the vegetation cover of southern Yenisei Siberia. In Domestic Geobotany: Milestones and Future Prospects. St. Petersburg, Russia. p. 411-415.

USSR Forest Map. 1973. Forest Map 1:1 500 000. Moscow, Russia. Roskartografia Press. 